\title{
Multiple Eclipse Naevi on Scalp of a Child: Awareness Can Prevent Unnecessary Surgery
}

\section{Çocukta Skalp Yerleşimli Multipl Eklips Nevüs: Farkındalık Gereksiz Cerrahiyi Önleyebilir}

\author{
Nilay Duman, Gül Erkin Özaygen*, Gonca Elçin* \\ Afyonkarahisar State Hospital, Clinic of Dermatology, Afyonkarahisar, Turkey \\ *Hacettepe University Faculty of Medicine, Department of Dermatology, Ankara, Turkey
}

Keywords

Eclipse naevus, signature naevus, dermatoscopy

Anahtar kelimeler

Eklips nevüs, imza nevüs, dermatoskopi

Received/Geliş Tarihi : 18.07.2013

Accepted/Kabul Tarihi : 13.06.2014

DOI: $10.4274 /$ jcp .96158

Address for Correspondence/Yazışma Adresi: Nilay Duman MD, Afyonkarahisar

State Hospital, Clinic of Dermatology,

Afyonkarahisar, Turkey

Phone: +90 5324713252

E-mail: nilybayram@hotmail.com

(C) The Journal of Current Pediatrics, published by Galenos Publishing. (c) Güncel Pediatri Dergisi, Galenos Yayınevi tarafından basılmıştır.

\begin{abstract}
Eclipse naevi are a kind of signature naevi that are mostly observed on trunks of adults and on scalps of children. As they can have some of the criteria for melanoma and can be difficult to follow up especially when they are located on scalp, removal might be recommended frequently by dermatologists. However they are actually benign and they only need observation. In this report a child with multiple eclipse naevi on scalp was described and literature data about eclipse nevus was reviewed to make physicians to be aware of this innocent lesion and to prevent unnecessary surgical procedures. Fifteen years old boy presented with 8 similar naevi on scalp characterized by tan homogenous centers and brown peripheral rims. Dermatoscopy of the lesions demonstrated central homogenous tan areas that were structureless except focal globules and regular brown pigment networks in the periphery. Excisional biopsy of a lesion was done and histopathological diagnosis was consistent with benign compound melanocytic naevus. With these findings diagnosis of eclipse naevus was made. To be aware of eclipse naevi is important to prevent unnecessary concern and surgical procedures.
\end{abstract}

$\ddot{\mathbf{O} z}$

Eklips nevüsler erişkinlerde sıklıkla gövdede, çocuklarda ise skalpte izlenen imza nevüs tipidir. Bazı melanom kriterlerini taşıyabildikleri ve de özellikle scalp yerleşimli olduklarında takipleri zor olabildiği için sıklıkla dermatologlar tarafından eksizyonları önerilmektedir, gerçekte benign lezyonlar olup sadece klinik takipleri yeterlidir. Burada skalp yerleşimli eklips nevüsleri olan bir vaka eşliğinde eklips nevüs hakkındaki literatür bilgisine yer verildi. Doktorların bu masum lezyon hakkındaki farkındalığının arttırılarak gereksiz cerrahi işlemlerin önlenmesi amaçlandı. On beş yaşındaki erkek hasta, skalp yerleşimli toplam 8 adet birbirine klinik olarak çok benzer ortası ten renginde, homojen, periferi regüler, koyu kahverengi halkaya sahip nevüslerle başvurdu. Lezyonların dermoskopik incelemesinde merkezde ten rengi homojen yapısız alan ve fokal globüller ve periferde koyu kahve regüler bir retiküler pigment ağı izlendi. Bir lezyonun eksizyonu yapıldı. Histopatolojik tanı benin bileşik nevüs ile uyumlu idi. $\mathrm{Bu}$ bulgularla eklips nevus tanısı kondu. Eklips nevüslerin farkında olmak gereksiz cerrahi işlemlerin önlenmesi açısından önemlidir. 


\section{Introduction}

Signature naevi are predominant group of naevi with similar clinical appearance in a patient. Eclipse naevus is a type of signature naevus and it is clinically characterized by a tan center and a brown peripheral rim (1). Although it is mostly seen on the trunk of adults, this type of naevus has also been described on the scalp of children (2). Because eclipse naevi can have some of the ABCDE (asymmetry, border irregularity, color variegation, diameter $\geq 6 \mathrm{~mm}$, and/ or evolution) criteria for melanoma, removal might be recommended, however they are actually benign and they only need observation. In this report a child with eclipse naevi on scalp was described and literature data about eclipse naevi was reviewed.

\section{Case}

Fifteen years old boy presented with brown lesions on the scalp which appeared suddenly within one month. The lesions were asymptomatic. The patient had skin phototype III. Melanoma risk factor evaluation was unremarkable except history of intermittent ultraviolet exposure for 3 years. Dermatological examination revealed 8 similar naevi with tan homogenous centers and brown peripheral rims on scalp (Figure 1). Dermatoscopy of the lesions demonstrated central homogenous tan areas that were structureless except focal globules and regular brown pigment networks in the periphery (Figure 2). Excisional biopsy of a lesion was done and histopathological diagnosis was consistent with benign compound melanocytic naevus. With these findings diagnosis of eclipse naevus was made. And as all lesions were similar, eclipse naevus was thought to be signature naevus of the patient. And clinical follow up was recommended for remaining naevi.

\section{Discussion}

The term "eclipse naevus" was firstly described in 2001 by Schaffer et al. as "a type of melanocytic naevus that is two-tone and has an irregular outline, but is benign" (3). Eclipse naevus is mostly observed in adults in third decades (2). However it has also been described on the scalp of children $(2,4)$. In a study evaluating 88 scalp naevi of 39 children, the main clinical patterns included eclipse $(n=18)$, cockade $(n=3)$, solid brown $(n=42)$ and solid pink $(n=25)$ naevi (4).
Clinically eclipse naevus is characterized by a tan center and a brown peripheral rim. Peripheral rim can be discontinuous leading to asymmetry, irregular pigmentation and irregular outline (1). Its diameter is frequently greater than $6 \mathrm{~mm}$ (5). The most common location is the trunk but other locations such as the arms and legs have also been reported (2). Pink eclipse naevus is a variant of eclipse naevus with a pink central portion that is seen in fair-skinned individuals (1).

Etiopathogenesis of eclipse naevi is not known exactly. The effect of immune responses is suggested to play a role (6). Some people with eclipse naevi also have cockade naevi that is characterized by a small central pigmented portion, an intervening nonpigmented zone and a peripheral pigmented ring

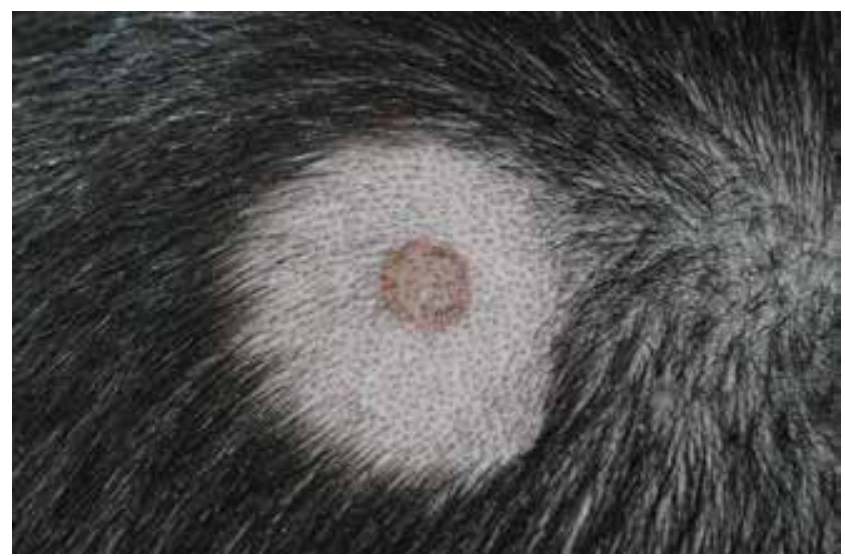

Figure 1. A melanocytic naevus with a tan homogenous center and brown peripheral rim on scalp (Nikon D70 camera, at x5 magnification)

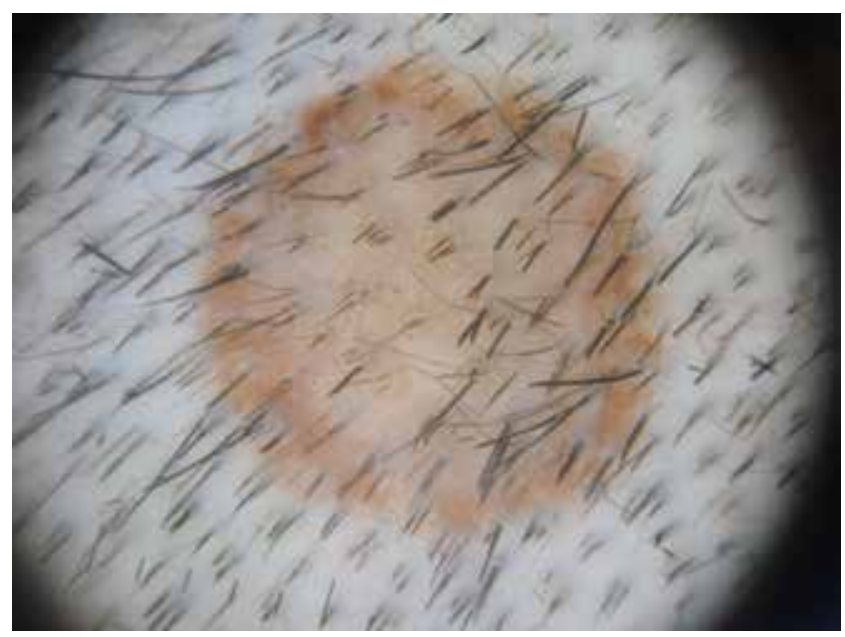

Figure 2. Central homogenous tan area with focal globules and peripheral regular brown pigment network (DermLite photo equipment, at x10 magnification) 
$(1,3,6)$. Some authors believe that eclipse and cockade naevi may be two different clinical variants of the same process triggered by sun exposure (5).

Histopathological examination of eclipse naevus is consistent with compound naevus with junctional shoulder and intradermal component. The junctional shoulder shows prominent pigmentation and there is decreased junctional pigmentation over the central intradermal component. Sometimes in the central portion prominent fibrosis of the papillary dermis is observed. Dysplastic changes are not observed $(2,3)$.

Despite potential worrisome features such as diameter larger than $6 \mathrm{~mm}$, irregular outline, asymmetry and irregular pigmentation, eclipse naevi are benign compound naevi $(2,3,5)$. Dermatologists frequently have tendency to recommend the excision of melanocytic naevi located on scalp, resulting in formation of permanent scars and localized hair loss. However eclipse naevi actually do not need surgical excision (5).

In conclusion, to be aware of this kind of naevi is important to prevent unnecessary concern and surgical procedures. Instead of unnecessary surgical procedures we recommend regular skin examinations in children with eclipse naevi on scalp.

\section{Ethics}

Informed Consent: Informed consent was obtained from the patient.

\section{Authorship Contributions}

Surgical and Medical Practices: Nilay Duman, Gül Erkin Özaygen, Gonca Elçin, Concept: Nilay Duman, Design: Nilay Duman, Data Collection or Processing: Nilay Duman, Gül Erkin Özaygen, Gonca Elçin, Analysis or Interpretation: Nilay Duman, Gül Erkin Özaygen, Gonca Elçin, Literature Search: Nilay Duman, Writing: Nilay Duman, Conflict of Interest: No conflict of interest was declared by the authors, Financial Disclosure: The authors declared that this study has received no financial support, Hakem Değerlendirmesi: Editörler kurulu dişında olan kişiler tarafindan değerlendirilmiştir.

\section{References}

1. Suh KY, Bolognia JL. Signature nevus. J Am Acad Dermatol 2009;60:508-14.

2. Fernandez-Flores A. Eponyms, morphology and pathogenesis of some less mentioned types of melanocytic nevi. Am J Dermatopathol 2012;34:607-18.

3. Schaffer JV, Glusac EJ, Bolognia JL. The eclipse naevus: tan centre with stellate brown rim. Br J Dermatol 2001;145:1023-6.

4. Tcheung WJ, Bellet JS, Prose NS, Cyr DD, Nelson KC. Clinical and dermoscopic features of 88 scalp naevi in 39 children. Br J Dermatol 2011;165:137-43.

5. Kessides MC, Puttgen KB, Cohen BA. No biopsy needed for eclipse and cockade nevi found on the scalps of children. Arch Dermatol 2009;145:1334-36.

6. Yazici AC, Ikizoğlu G, Apa DD, Kaya TI, Tataroğlu C, Köktürk A. The eclipse naevus and cockade naevus: are they two of a kind? Clin Exp Dermatol 2006;31:596-7. 